ISSN: 2638-6062

\title{
Rett Syndrome: Reporting A Case and Review in Literature
}

\author{
Gabriel Miranda Nava* \\ Department of Neurology, Centre of Military Hospital, Mexico, USA
}

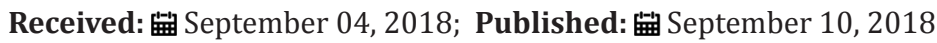

*Corresponding author: Gabriel Miranda Nava, Head of Neurology, Centre of Military Hospital, Mexico, USA

Keywords: Rett Syndrome; Psychomotor retard; MECP2 gene; Baden-Baden criteria

\section{Opinion}

Rett syndrome is a disorder in children's neurological development characterized by an initial normal evolution followed by the loss of voluntary use and characteristic movements of the hands, a delayed growth of the brain and head, difficulty walking, seizures and mental retardation. The syndrome affects almost exclusively girls and was identified by Dr. Andreas Rett in 1966.

\section{Case Report}

Female patient of 9 years of age who is unknown the beginning of her condition since it is the product of the penultimate feat of 6 in total and they did not take care of her since her mother was engaged in prostitution, a part of being beaten and sexually assaulted. It is seen in the House of Angels in the City of Puebla for children with mental problems. Clinically it is known from 3 years of age, time that the institution lives. Since then it is observed with autoagresiones, psychomotor retardation and of growth, with diminution of the cephalic perimeter, it is known that it has epilepsy from the 6 months of age with a difficult control of its crisis as well as an autistic behavior; the fluttering of his hands is striking in a random, symmetrical way and even sometimes merits subjection as it becomes self-injuring.

\section{Summary}

\section{Rett's Syndrome}

"A case report and bibliography review".

\section{Introduction}

The Rett syndrome is a rare disorder of the neurological development of the central nervous system, like in the child neurological development characterized by a normal evolution follow by lose of voluntary skills and hand's special movements, a slowly head and brain's growth, difficult walking, seizures and mental retardation. This syndrome affects exclusively girls and was identified by Dr. Andreas Rett in 1966.

\section{Case Report}

A 9-years old girl patient who unknowns about her disease beginning because she's the result of the fifth birth of six, because her mother doesn't care her, she was a prostitute, in addition the girl suffers sexual and physical attacks. She was seen in the City of Puebla in the Angel's House for children with mental diseases. The patient is met for 3 years old, since this time she shows injures to herself, psychomotor and growth retard, decrease of cephalic perimeter, epilepsy since she was 6 months of age, hard control of crisis and autism behavior; random symmetric rumble of hands, it's necessary to hold for she doesn't injure herself. 


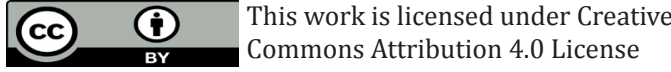

To Submit Your Article Click Here: Submit Article

DOI: $10.32474 /$ PRJFGS.2018.02.000136

\begin{tabular}{|c|c|}
\hline PRJ & $\begin{array}{c}\text { Peer Reviewed Journal of Forensic } \\
\text { \& Genetic Sciences }\end{array}$ \\
\hline & $\begin{array}{l}\text { Assets of Publishing with us } \\
\text { - Global archiving of articles } \\
\text { - Immediate, unrestricted online access } \\
\text { - Rigorous Peer Review Process }\end{array}$ \\
\hline 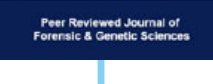 & $\begin{array}{l}\text { - Authors Retain Copyrights } \\
\text { - Unique DOI for all articles }\end{array}$ \\
\hline
\end{tabular}

